\title{
THE YANNARIE SOLAR PROJECT: DESIGN OF A SOLAR SALTFIELD IN WESTERN AUSTRALIA TO SAFEGUARD THE NATURAL ENVIRONMENT
}

\author{
R. MOTTERSHEAD ${ }^{1}$ \\ P. DAVIDSON ${ }^{2}$
}

${ }^{1}$ CGV Pty. Ltd.

Perth, Western Australia

${ }^{2}$ Straits Resources Limited.

Perth, Western Australia
Received: $27 / 08 / 08$

Accepted: 15/12/08 *to whom all correspondence should be addressed: e-mail: rmotters@bigpond.net.au

\section{ABSTRACT.}

The Northwest Coast of Western Australia is the location for a number of large solar saltfields. More than 10 million tonnes of high grade solar salt is exported annually from these saltfields; predominantly servicing the chloralkali industries of Northern and Southeast Asia.

Straits Resources Limited is a mining company with operations in Australia and Indonesia. It has identified the solar salt industry as an opportunity to diversify its resource portfolio and build a longer-term position within the resource sector. Access has been approved by the Government of Western Australia to a large area in the eastern Exmouth Gulf region of Western Australia suitable for a solar saltfield with an ultimate capacity as high as 10 million tonnes per annum.

All new resources projects in Australia must proceed through a rigorous environmental approval process at both the Federal (Commonwealth) and State Government levels.

Straits commissioned a team of saltfield design, environmental and engineering consultants to design an economically viable saltfield that minimises impacts to the environment. There has been a series of iterative changes in its design based on feedback from environmental and cultural heritage studies. This has enabled the saltfield to be specifically located within a defined footprint to avoid sensitive areas such as mangroves, tidal creeks and algal mats.

Comprehensive studies have been undertaken on the local marine and terrestrial flora and fauna (including migratory bird and marine fauna), together with surveys for cultural heritage, soils, hydrology and a sweep of other parameters including hydrodynamic modelling of the marine environment. A commercial trawling fishing industry operates in the waters of Exmouth Gulf that is also the permanent home or on the migratory path of a number of significant marine fauna, including whales, turtles, and dugongs.

The project, known as the Yannarie Solar Project, is progressing through the environmental approval processes of the Australian Commonwealth and Western Australian Governments. The conclusion is that the technical findings of the suite of studies that examined the environmental aspects of the engineering requirements of the saltfield provide a sound basis for project approval. Assuming that approval is given, and the current schedule maintained, construction would commence in 2008 and shipments of salt in 2011.

KEYWORDS: solar saltfield, Yannarie, environment, Western Australia.

\section{INTRODUCTION}

By 1972, four large solar saltfields in Western Australia (Fig. 1) were servicing the growing need for high quality solar salt for the Japanese, South Korean and Taiwanese chemical industries. Exports of solar salt from Western Australia exceeded 10 million tonnes in 2006. China began importing salt in significant quantities for the first time. The only major competitor in the principal markets of Japan, South Korea and Taiwan remains the Mexican solar salt producer - Exportadora del Sal (ESSA). This saltfield is currently the largest in the world, with capacity exceeding 8 million tonnes per annum. 
Straits Resources Limited is a mining company with operations in Australia and Indonesia. It is seeking opportunities to promote sustainable projects applicable to its areas of expertise. The solar salt industry represented one such opportunity. A number of sites were studied, and the Exmouth Gulf region appeared to offer the best opportunity for establishing a sustainable solar salt project. A scoping study confirmed that the area available could eventually support production of 10 million tonnes of salt per annum. This would make the project the largest solar saltfield in the world. The project is now referred to as the Yannarie Solar Project.

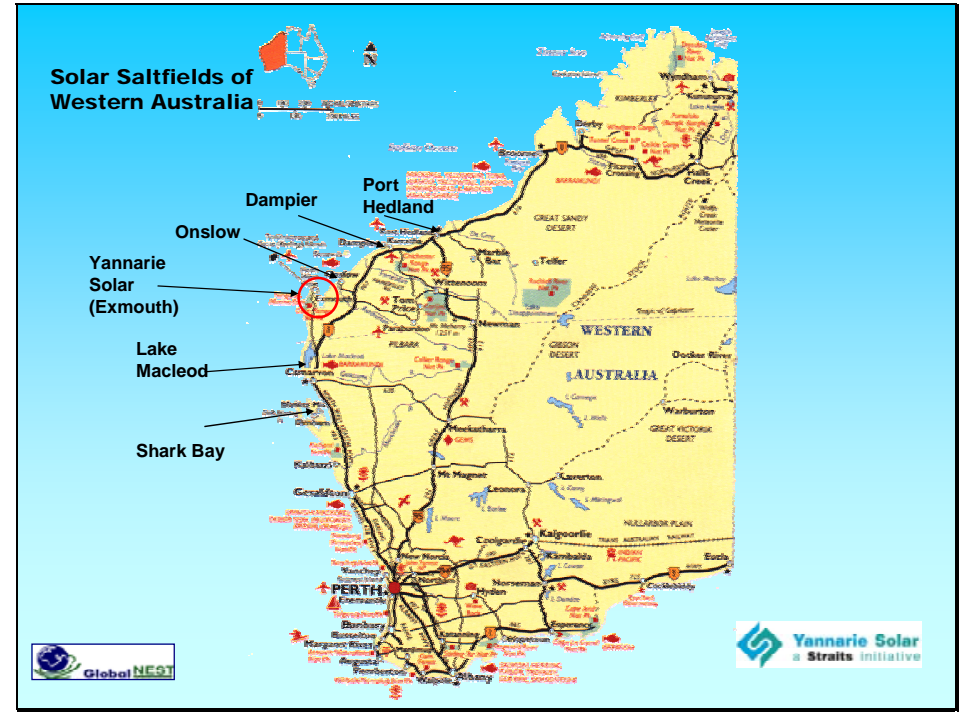

Figure 1. Saltfields of Western Australia

Approval to proceed with major resource projects in Australia is only obtained after environmental studies have been undertaken. There studies must meet the regulatory requirements of both the Australian Federal Government in Canberra and, in the case of the Yannarie Solar Project, the West Australian Government in Perth. This paper summarises the fluid interaction between the designers of the field and the environmental specialists as these studies progressed.

\section{SOLAR SALTFIELDS IN WESTERN AUSTRALIA}

Shark Bay Salt commenced shipments of salt in 1967 from the Shark Bay field. Dampier Salt (at Dampier), Leslie Salt (Port Hedland), and Texada Mines (Lake Macleod) were all fully operational by 1972. These four producers were successfully competing with Exportadora de Sal in Mexico, which remains the world's largest solar saltfield. The high quality product from these producers was replacing the lower quality salt from solar saltfields in other countries, including China and India.

The main customers for Australian and Mexican solar salt in Japan are producers of caustic soda, chlorine and soda ash. The majority of chloralkali plants in Japan in the 1960s used the mercury process to produce caustic soda and chlorine.

Environmental concerns led to the closure of the mercury cell technology used at many chloralkali plants in Japan. Whilst some of these mercury plants were replaced by the diaphragm process, development of a new, more efficient technology was rapidly evolving. This new technology - known as the ion exchange membrane process - quickly dominated the Japanese replacement market for chloralkali projects. The membrane cell requires a very pure salt feedstock. Purification costs involved in removing any residual impurities in the feedstock salt can be significant. Hence the need for high quality feedstock salt as being supplied by the Australian and Mexican producers.

Synthetic production of soda ash from salt was being replaced in Japan by imports of soda ash from the trona ore deposits found in abundance in the US.

Hence, the major growth in demand for solar salt in Japan, followed by South Korea, Taiwan and Indonesia came from new ion exchange membrane chloralkali plants. Expansions at the 
Australian and Mexican solar saltfields continued to satisfy this increase in demand through the '80s and '90s. The next major field commissioned in Western Australia was Onslow Salt, which made its first shipment in 1997.

The solar salt industry in Western Australia has thus proved its sustainability, through an integrated mix of effective and efficient operational and environmental practices. No major environmental issues have been raised; bearing in mind that this area of Western Australia has extensive marine, pastoral, tourism and cultural interests.

The Northwest coast of Western Australia is also an area impacted upon by major cyclonic activity on an annual basis. Complex models have been developed to statistically predict the frequency and intensity of cyclonic activity. Engineering standards, therefore, have been specifically developed to ensure that damage to the pond systems is minimised within economic constraints. All of the solar saltfields in Western Australia have been damaged by wind-driven waves and surges experienced during cyclonic events. Location and production diversity among the Western Australian producers has ensured that customer needs continue to be substantially met during the rebuilding period.

\section{STRAITS RESOURCES' YANNARIE SOLAR PROJECT}

Following a detailed evaluation of potential sites for a solar saltfield, Straits concluded that the Exmouth Gulf region of Western Australia provided the best opportunity for a long-term sustainable project.

The area of flat mudflats stretches more than $100 \mathrm{~km}$ from south to north and varies between a few kilometres and $10 \mathrm{~km}$ in width between the mangrove region and the hinterland (Fig 2.)

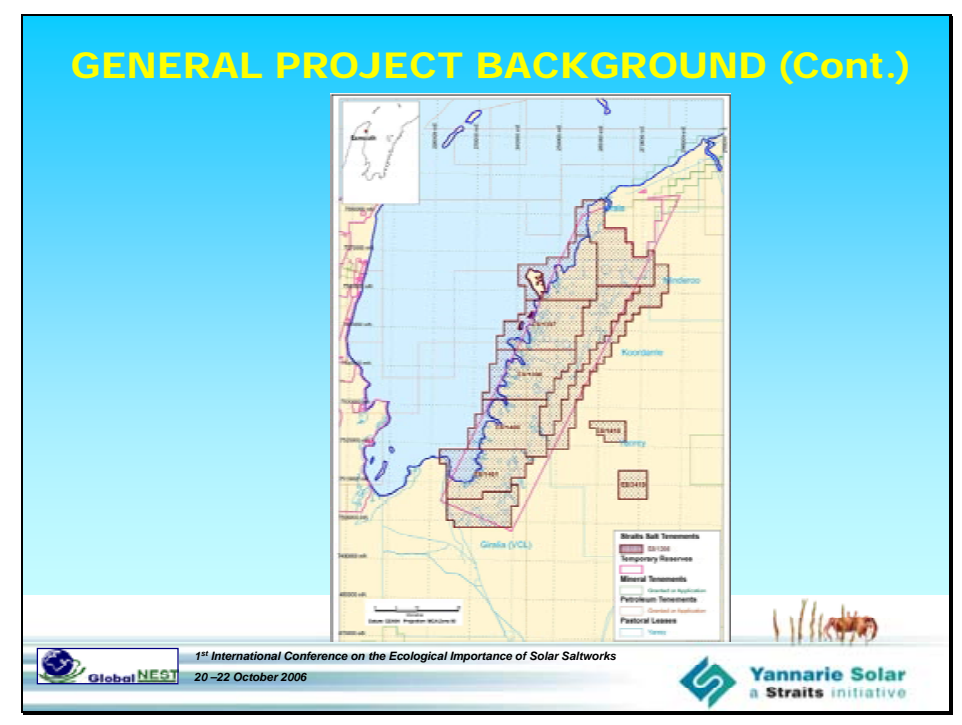

Figure 2. Exmouth Gulf Lease Area

Straits obtained a number of Exploration Licenses from the Government of Western Australia. The licences give Straits the exclusive rights to evaluate the area for solar salt purposes, with a requirement to submit proposals for development.

\section{SCOPING STUDIES}

The objective of the scoping study for the Yannarie Solar Project was to assess the commercial potential of the exploration licences for developing a solar salt operation. Consultants with extensive experience in the design, construction, operation and marketing of solar salt in Western Australia complemented the in-house engineering and environmental expertise of Straits.

The scoping studies were complete by September 2003. The results concluded that an initial operation to produce around 3 million tonnes of high quality solar salt would be viable and sustainable. Confirmation was also made that full development of the area could support an operation of around 10 million tonnes per annum. This would make the Yannarie Solar Project 
the single largest solar saltfield in the world, exceeding the capacity of Exportadora de Sal in Mexico.

A referral document was submitted to the Western Australian Environmental Protection Authority (EPA) in April 2004, outlining the company's plans to develop a 10 million tonne per annum solar saltfield.

The EPA determined that the level of assessment for the project would be set at Environmental Review and Management Programme (ERMP). This is the highest level of assessment for resource-based projects in Western Australia. In accordance with a bilateral agreement between the Commonwealth Government of Australia and the States, the terms of the ERMP would also meet the requirements of the Commonwealth Government. Fig 3 provides details of the approval process.

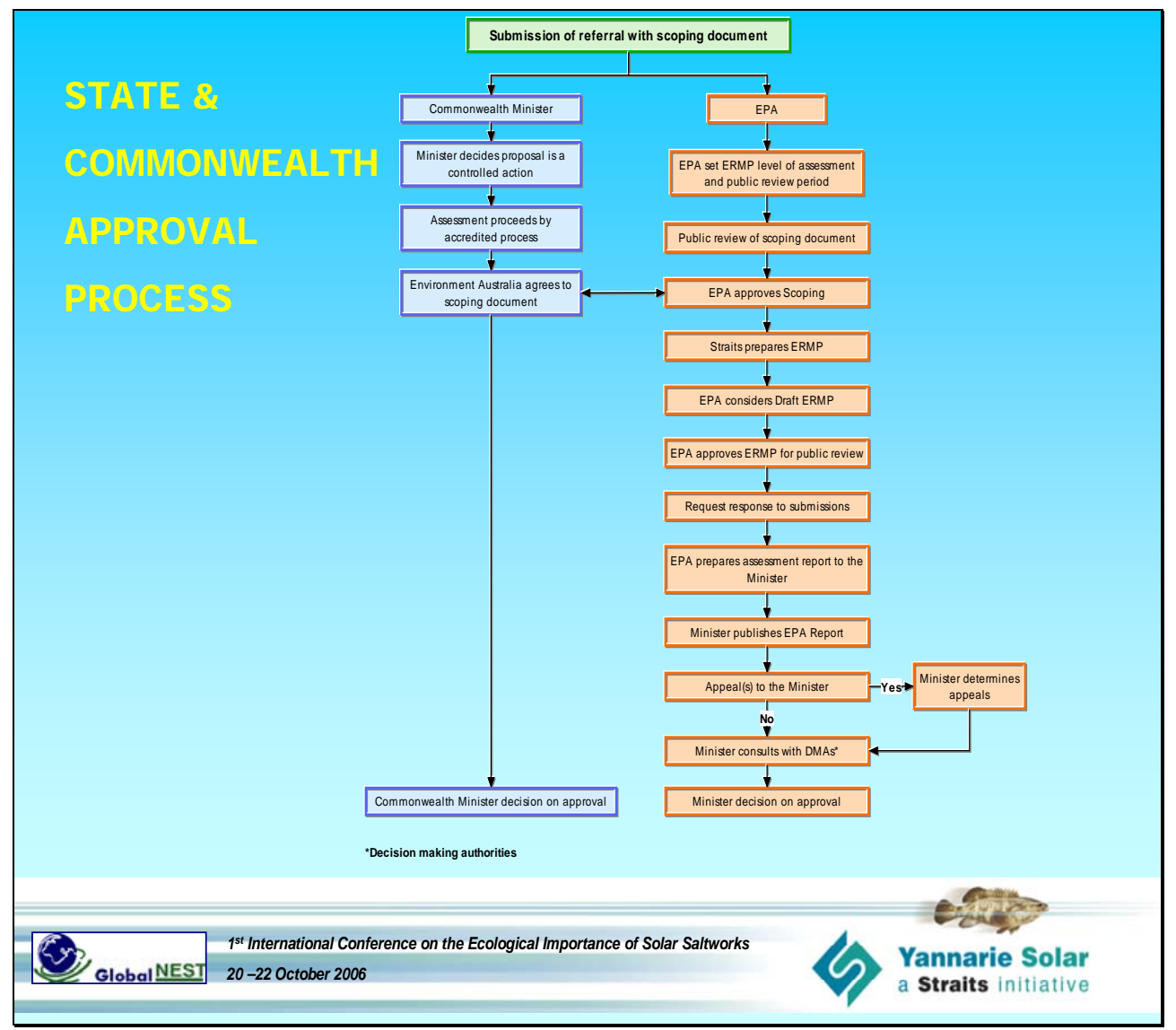

Figure 3. Environmental Approval Process

Preliminary engineering design was conducted in parallel with the environmental studies and a finalised design provided with the ERMP document.

\section{BASIC FIELD DESIGN}

A solar saltfield brine mass balance programme has been developed for the design and layout of the proposed multi-stage Yannarie Solar Project. The ultimate capacity of 10 million tonne per annum will probably be achieved through four stages - two to the south of the proposed crystalliser pond area, and two to the north (Fig. 4). 


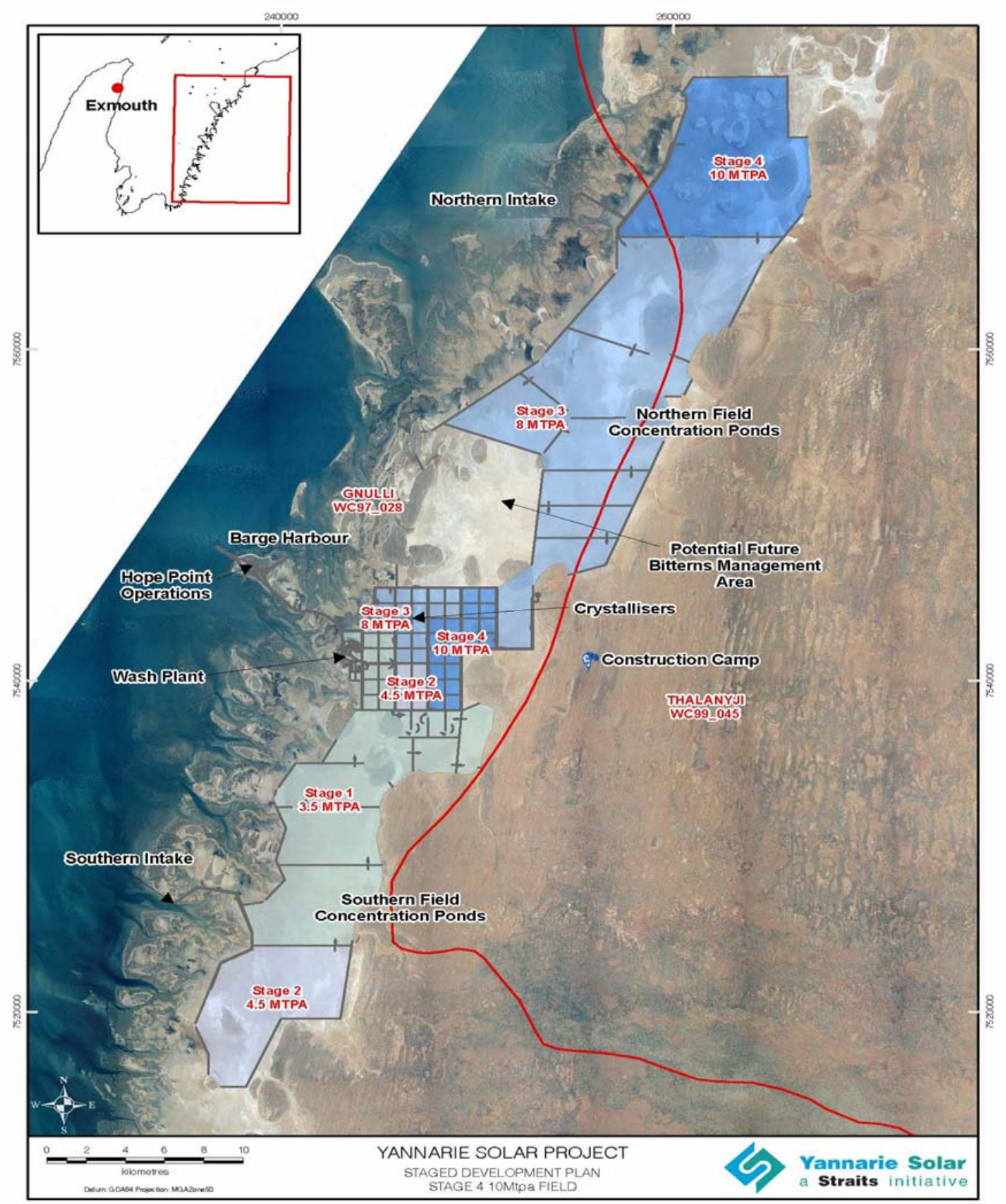

Figure 4. Proposed 4-Stage Development of Yannarie Solar Project.

Bonython led the way in the theoretical and practical design of large solar saltfields (Bonython, 1966). Baseggio's work on the composition of seawater and its components remains valid, and has been extensively used in the design of the Yannarie Project (Baseggio, 1974). McArthur worked closely with Bonython in the establishment of the Dampier field (McArthur, 1980) and assisted with the development of integrated management practices at large solar saltfields. Burnard subsequently developed a computer model for process control at Dampier (Burnard, 1993).

The key data required for solar saltfield design include evaporation and precipitation rates at the specific site, together with topographical and geotechnical information.

Historical data of freshwater evaporation rates in standard evaporimeters, and rainfall, are now readily available from numerous stations along the coast of Western Australia. Monthly evaporation rates vary significantly. However, monthly evaporation is always in excess of 
rainfall except for those months when exceptional rainfall occurs, mainly during periods of cyclonic activity. Seepage rates are assessed at the project site. Average annual rates for freshwater evaporation, rainfall and seepage are used for preliminary pond design. The critical unknown at greenfield sites is the rate of evaporation of brine at varying densities in the concentration and crystalliser ponds. It is well known that this rate varies from month to month for brine at salting point. Extensive annual and monthly brine mass balances have now been conducted at a number of solar saltfields in Western Australia. Based upon this work, an equation was developed for the variation in the estimated monthly evaporation rates of saturated brine at the project site. Burnard's work was then used to establish rates at varying densities. Baseggio's work was used to develop equations for the changes in the key ionic compositions of the brine at increasing densities.

A base brine mass balance programme was developed for an average field capacity of 3 million tonnes per annum. The programme was then adjusted to optimise pond areas, pond numbers, and brine densities in each pond.

The programme was then further developed to provide monthly volumes for seawater intake requirements, saturated brine supply to crystallisers, and output rates of the residual bitterns brine.

The programmes were consolidated at the proposed initial base capacity of $3 \mathrm{Mtpa}$, based upon a seawater density of $1.026 \mathrm{~g} \mathrm{ml}^{-1}$. saturated feed brine density of $1.216 \mathrm{~g} \mathrm{ml}^{-1}$. and output bitterns density of $1.25 \mathrm{~g} \mathrm{ml}^{-1}$. all at $20^{\circ} \mathrm{C}$. The programmes have been further developed to include a) recovery of salt lost in the washing process, b) additional salt recovery from brines at densities beyond $1.25 \mathrm{~g} \mathrm{ml}^{-1}$. and c) the recovery of mixed salts of magnesium and potassium. The ultimate capacity field design of $10 \mathrm{Mtpa}$ assumed a fourstage development.

\section{BASIC FIELD LAYOUT AND ENGINEERING}

To enable the environmental studies to proceed, a preliminary layout of the 10 Mtpa field was established (Fig. 4).

The brine mass balance programmes developed are flexible enough to readily adjust the layout as required to avoid environmentally sensitive areas, or areas unsuitable for levee construction. Final layouts will only be confirmed following detailed topographic and hydraulic studies. Levee alignments may also be adjusted when further studies are done on prevailing wind conditions and on the need to ensure the ponds will establish a sustainable biological system. A number of options were also studied for possible seawater pumping sites.

Following a commitment by Straits to store or utilise bitterns for a minimum of 10 years, thus precluding their release back into Exmouth Gulf for this period, an area was set aside for this purpose.

A number of options were evaluated for the location of washing, stockpiling and shipping facilities. Current proposals favour Main Island for the washplant (Fig. 5).

Hope Point provides an ideal location for a barge basin protected from the ocean, with minimal dredging of a channel to provide full tidal operation of the barges. The washed salt will be conveyed to Hope Point where it will be stockpiled prior to export.

As this area of Western Australia is impacted by the annual cyclone season, all facilities must be designed accordingly. An assessment of cyclone-generated storm surges will enable final design of the levees, access roads and causeways. The area to the southeast of the southern ponds is a significant catchment area. During periods of intensive rain, this area can discharge freshwater onto the mudflats. This water would normally flow across the mudflats and release in to the creek system of the Gulf. The design of the field will accommodate a suitable diversion system for this flow. 


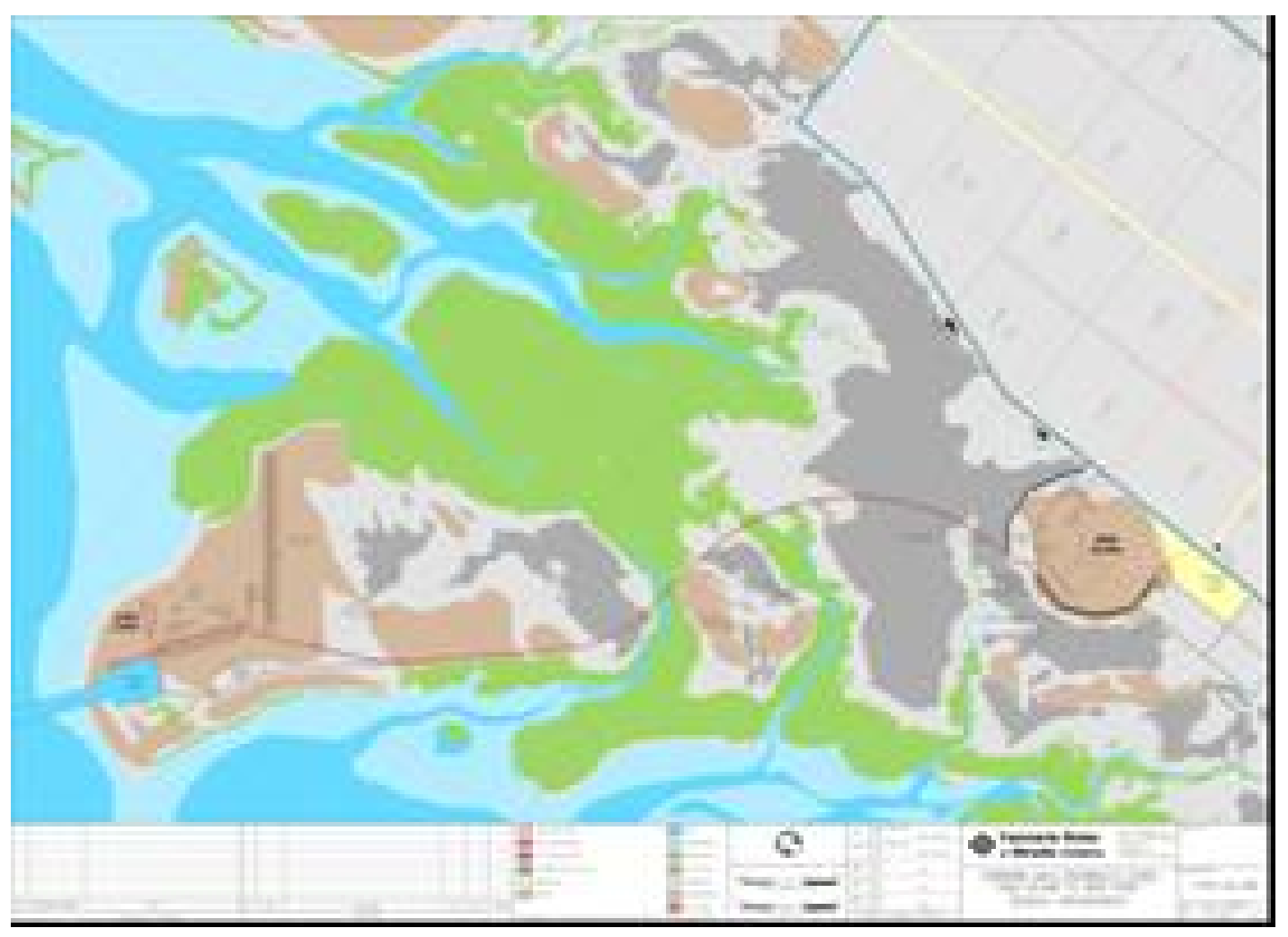

Figure 5. Hope Point \& Main Island Facilities and joining causeway

\section{AUSTRALIAN ENVIRONMENTAL LEGISLATION AND REGULATIONS}

The two key legislative areas operating for solar salt mines in Western Australia are the Mining Act,1972 and the Environmental Protection Act, 1986 (EP Act), unless project specific Acts of Parliament (State Agreement Acts) are put in place. The Minister for the Environment of the Government of Western Australia may approve projects, subject to compliance with legislation and regulations of a number of other State Government bodies. For the Yannarie Solar Project this compliance relates to 15 Acts. The Environmental Protection Act 1986 is the principal statute relevant to environmental protection in Western Australia. If the project is deemed to have a significant impact on a matter of National environmental significance, approval is also required by the Federal Minister for the Environment and Heritage (Environmental Protection and Biodiversity Conservation Act, 1999). A number of State Government policies and guidelines are also applicable to the assessment process.

Under the EP Act, there are a number of tiers of assessment triggering increasing levels of public involvement in the assessment of a proposal depending on the number and type of environmental sensitivities. Proposals in sensitive coastal ecological systems, particularly mangroves, tend to trigger the highest level of environmental assessment. Hence, the process commences with the proponent submitting an overview document that states the project scope and key environmental considerations that then allows the State and Federal Environmental agencies to set the level of public assessment. This is advertised. In the case of the Yannarie Solar Project, the environmental impact assessment was set at an "Environmental Review and Management Programme" (ERMP) or highest level. Following this, the proponent is required to submit an ERMP Scoping Document to the Environmental Protection Authority (EPA) for review and is subsequently advertised in the public domain for comment on the nature and scope of environmental impact studies that will provide the fundamental information to assess the impacts of the proposal.

Once approved, the investigations are then implemented, completed and consolidated into a draft ERMP that is effectively an Environmental Impact Statement and a set of management plans and commitments to prevent or minimise environmental impact. This is then submitted to the EPA for review, and on confirmation that it meets the requirements as outlined in the Environmental Scoping Document; it is then approved for release to the public. A formal 10- 
week public assessment period then commences. Public submissions are received by the EPA and collated with comments from all key decision making authorities which the proponent must then formally respond to and submit this response to back to the EPA..

The final ERMP assessment is made by the EPA taking all of this into consideration and a recommendation made to the Minister for the Environment in the form of an EPA Bulletin that is made publicly available. Following consideration of any appeals, the Minister may approve the project, subject to agreed environmental controls and commitments by the proponent.

Throughout this ERMP process, Straits set up a Stakeholder Consultation Plan aimed at keeping all key stakeholders fully advised through to and post the submission of the ERMP to the EPA.

This project approval process is thorough, expensive and time-consuming. However, it aims to assist the State in minimising impacts to the environment and maximising social benefits, while allowing economically viable project to proceed.

While meeting the requirements of the EP Act, a specific Mining Proposal must also be developed under the Mining Act and secondary approvals also need to be sought (Dangerous Goods Licensing for hydrocarbons, specific permits relating to water and rivers, land clearing, construction, roads, and numerous others legislative requirements). The Mining Proposal will also allow the project to secure land tenure (Mining Leases or Agreement Act) and will trigger the Native Title Process whereby agreements with indigenous landholders will be required, that will then allow the project to proceed once statutory mine reclamation bonds are lodged with the Department of Industry and Resources.

\section{KEY ERMP STUDIES}

The key areas of environmental impact studies included: soils and landforms; surface hydrology; groundwater; terrestrial flora and vegetation; terrestrial fauna (including migratory birds); specific studies on mangroves and algal mats, seagrasses, marine algae, sponges and corals; hydrodynamic changes;, marine fauna (including large marine mammals); climatic modelling; emissions assessments; noise and dust and visual amenity impacts; environmental and project risk assessments; social impacts; hydrocarbon spills assessments; indigenous heritage (archaeological and anthropological assessments); shipping impacts (including marine ballast water), collisions with marine fauna, antifouling agents, anchorage and transhipment corridors; and potential impacts of various bitterns discharge scenarios amongst a number of other supportive studies and specific engineering studies to compliment and better define the project footprint and how this may affect the environment.

The ERMP structure deals with the environmental factors by outlining the:

- EPA Objectives. The primary objectives are those prescribed by the EPA after consideration of the proposal-scoping document.

- Legislative Policy and Context. Identifies key requirements that relate to the factor.

- Description of Factor. Provides description of the factor and potential impacts due to the proposal.

- Impact Assessment and Mitigation. Identifies proposal activities that potentially affect the environmental factor and describes mitigation of the impact.

- Monitoring Assessment of Performance. Outlines monitoring programs to assess the effectiveness of the management measures.

- Proponent Commitments. Provides a review of existing proponent commitments and presents updated commitments.

- Environmental Outcome. A summary description of residual impacts and consideration of the likelihood of outcome being achieved.

The requirements of the Mining Proposal duplicate much of the ERMP; however, it requires the inclusion of staged development plans, mining operation plans, conceptual closure information, manpower requirements and economic parameters.

\section{ENVIRONMENTALLY-DRIVEN ADJUSTMENTS}

A key aspect to the environmental impact studies has resulted in the ability to make numerous engineering adjustments to reduce the impacts of the project on the environment. Adjustments have been made to the layout of the ponds and facilities in response to the key 
environmental issues raised or new information becoming available as the environmental studies progressed. Ingress into the mangrove and algal mat areas has been minimised. Minor ingress is required between seawater pumping sites and the concentration ponds, and between the Main Island and Hope Point facilities. Should the Yannarie flood catchment area discharge onto the mudflats, diversion levees will direct the water to the south of the saltfield ponds. Options involving long trestle and jetty structures into the Gulf, or major channel dredging to permit vessel loading close to shore, were rejected in favour of the barge option. This option only requires the on-shore excavation of the barge basin and a short, shallow, dredged channel into the Gulf.

To minimise potential impact on the area by permanent housing of construction and operational employees, it is proposed to locate employees in Exmouth and transfer them to site on a daily basis, either by air or water transport.

\section{BITTERNS}

The residual bitterns brines from solar salt operations are normally discharged back into the ocean, or into associated creek and lagoon systems. In Western Australia, each of the salt producers currently disposes of bitterns, but only under agreed programmes with the EPA. Dilution of bitterns with seawater, and controlled release according to tidal flows are both agreed practices. The industry now has more than 40 years operational experience in controlled release of bitterns brines. No major environmental issues have been recorded which directly relate to these release programmes. Historically, minor fish kills have been recorded where agreed release programmes have not been adhered to. However, improved bitterns discharge regimes in recent times have either eliminated or minimised this occurrence.

As the Exmouth Gulf region supports a diverse marine system, the environmental studies included extensive hydrodynamic modelling of the area around Hope Point, assuming that bitterns would be released from that point. Whilst these studies confirmed that under controlled conditions, whereby the bitterns would be significantly diluted by seawater within the barge basin prior to their release in the basin, minimal impact would result and only upon the immediate area of the basin, Straits has nevertheless committed to zero bitterns discharge for a minimum of 10 years. During this time, Straits will study options for further utilisation of the bitterns and will proceed with processing projects as they become commercially viable. Recovery of potassium values as potassium sulphate fertiliser will be a principal objective.

Straits will also evaluate further innovative projects, including energy supply from solar ponds.

\section{CONCLUSION}

At the time of writing, the Yannarie Solar Project continues with the rigorous environmental approval process in Western Australia. Straits remain confident that the project will proceed and be sustainable, both internally from an economic viewpoint, and externally from an environmental perspective.

Through a series of planned stages, the project will convert a large waste mudflat area into a favourable ecological wetland, which will attract and sustain a full biomass range of organisms as are normally found at similar solar saltworks. The external environment will be protected and enhanced. The Exmouth Gulf region will continue to provide commercial and tourism opportunities.

\section{REFERENCES}

Baseggio G., (1974) The Composition of Sea Water and Its Concentrates. A.H. Coogan (Editor) Fourth Symposium on Salt. Northern Ohio Geol. Soc., Cleveland, Ohio.

Bonython C.W. and Myers D.M., (1958) The Theory of Recovering Salt from Sea-water by Solar Evaporation. J. appl. Chem., 8, 207-219.

Burnard E., (1993) The Use of Computer Models in Solar Salt Field Process Control. Seventh Symposium on Salt. Elsevier Science Publishers B.V., Amsterdam.

McArthur J.N., 1980. An Approach to Process and Quality Control Relevant to Solar Salt Field Operations in the Northwest of Western Australia. A.H. Coogan and L. Hauber (Editors), Fifth Symposium on Salt. Northern Ohio Geol. Soc., Cleveland, Ohio. 